\title{
Analisis Pengaruh Portofolio Kredit Terhadap Kualitas Kredit dan Profitabilitas pada BPR Konvensional di Riau
}

\author{
DIAN FEBRINA \\ Sekolah Tinggi Ilmu Ekonomi Riau \\ Jln. HR. Subrantas 57 Panam Pekanbaru 28293 Telp. (0761) 63237 \\ E-mail: dian_febrina84@yahoo.com
}

\begin{abstract}
The present research was conducted at Riau Province. The purpose of this research is to influence of credit portfolio to non perfoming loan (NPL) and profitability (ROA) in Bank Perkreditan Rakyat (BPR) Convensional in Riau. The population of this research is a Bank Perkreditan Rakyat Convensional from annual report are listed in Perbarindo Riau during 2009-2013 with the number of saturation samples are 33 BPR in Riau. This research apply on using portofolio credit based on a type of used that is working capital loan, investment loan and consumer loan as an exogenous variable, credit quality (NPL) as an intervening variable and profitability (ROA) as a endogenous variable. The data were analyzed using path analysis. The result of this study indicate that working capital loan through credit quality indirectly significant negative effect on profitability, but the working capital loan directly positive effect on profitability. While investmen loan and consumer loan positive impact on profitability either directly or indirectly throught credit quality. Finally, credit quality and negative significant effect on profitability.
\end{abstract}

Keywords: credit portfolio, working capital loan, investment loan, consumer loan, credit quality, non performing loan (NPL), profitability, return on assets (ROA) and path analysis.

Berbagai kebijakan Bank Indonesia dalam menumbuhkan iklim bisnis perbankan di Indonesia menjadi momentum pihak yang berkelebihan dana untuk membuka bisnis perbankan. Salah satunya adalah Bank Perkreditan Rakyat (BPR) baik yang dimiliki pihak swasta maupun pemerintah daerah.

Tujuan pendirian BPR salah satunya adalah meningkatkan pertumbuhan penyaluran kredit perbankan. Dalam hal ini, potensi usaha khususnya Usaha Mikro Kecil Menengah (UMKM) yang dapat dibiayai perbankan baik bank umum maupun Bank Perkreditan Rakyat di Riau yang relatif besar sehingga dapat mendorong pertumbuhan ekonomi Provinsi Riau (Perbarindo, 2009).

Menurut data Statistik Perbankan Indonesia, sampai dengan Oktober tahun 2013 jumlah bank umum yang beroperasi di Provinsi Riau mencapai 45 (empat puluh lima) bank, sementara jumlah Bank Perkreditan Rakyat Konvensional yang sudah beroperasi mencapai 33 (tiga puluh tiga) bank dan Bank Perkreditan Rakyat
Syariah/BPRS yang sudah beroperasi di Riau sejumlah 2 (dua) bank. Bisnis BPR baik yang beroperasi dengan konsep konvensional maupun syariah, memiliki peluang yang sangat menjanjikan. Dengan sentuhan personal yang kompeten dan profesional, langsung terjun ke lapangan membantu melakukan pembinaan terhadap usaha nasabah merupakan sebuah kekuatan bagi BPR dalam mengembangkan peluang bisnis tersebut yang pada gilirannya akan menghasilkan keuntungan. Seperti kutipan pada Hallo Riau (Januari, 2011), "Produktifitas Bank Perkreditan Rakyat (BPR) di Provinsi Riau ternyata lebih besar dibanding BPR yang ada di provinsi lain".

Berdasarkan data perkreditan, penyaluran kredit secara nasional menunjukkan peningkatan yang cukup besar. Pada tahun 2009 pertumbuhan kredit Bank Perkreditan Rakyat Konvensional adalah sebesar $16 \%$ dibanding tahun 2008, dan pertumbuhan kredit yang paling tinggi adalah tahun 2011 yang mencapai Rp 25,472 triliun 
dengan pertumbuhan sebesar $24 \%$ dibanding tahun 2010. Untuk tahun 2012 posisi kredit BPR Konvensional telah mencapai $\mathrm{Rp}$ 28,191 triliun, pertumbuhan ini diantaranya dipacu oleh kredit komsumsi.

Berdasarkan data Statistik Perbankan Indonesia bahwa penyaluran kredit oleh Bank Perkreditan Rakyat memprioritaskan pada kredit modal kerja, kredit konsumtif dan kredit investasi. Kredit modal kerja, kredit investasi, dan kredit konsumsi mengalami peningkatan dari tahun ke tahun. Hal ini menunjukan bahwa kondisi perkembangan BPR berjalan dengan sangat baik (BPR di Riau Lebih Produktif, Hallo Riau, 28 Januari 2011).

Tinggi rendahnya NPL akan berpengaruh terhadap profitabilitas suatu bank. Karena bank akan membuat suatu penghapusan penyisihan aktiva produktif terhadap kredit yang bermasalah (Peraturan Bank Indonesia, 2006). Perolehan laba yang diikuti peningkatan indikator profitabilitas menjadi ukuran keberhasilan operasional perbankan. Salah satu alat untuk mengukur profitabilitas adalah dengan menggunakan Return On Asset (ROA). ROA menunjukan peningkatan yang bermakna tercermin dari aktiva produktif, khususnya portofolio kredit karena portofolio secara perlahan-lahan telah mampu memberikan nilai bagi operasionalisasi perbankan dengan tetap memperhatikan prinsip kehati-hatian dalam mengalokasikan kredit (Retnardi, 2007).

Portofolio adalah jenis dari suatu asset yang jika dibuat suatu kombinasi yang baik dapat saling mengurangi resiko yang akan terjadi apabila asset tersebut diinvestasikan. Portofolio investasi suatu bank sangan berbeda dengan portofolio investasi suatu perusahaan dagang, dimana perbedaannya terletak pada keamanan modalnya, likuiditas, pertumbuhan, diversifikasi resiko kredit dan manajemen tingkat bunga.

Kredit merupakan aset utama pada hampir seluruh portofolio bank meliputi 50 s/d 70 persen dari total aset. Bagi kalangan masyarakat, kredit bank merupakan sumber utama pembiayaan, sedangkan bagi pihak bank sendiri, kredit merupakan penghasilan dengan porsi yang terbesar.

Portofolio kredit menurut Kasmir (2002) dapat terdiri dari:

1. Berdasarkan penggunaan dana, antara lain: a. Kredit modal kerja (working capital loan); b. Kredit investasi (investment loan); c. Kredit konsumsi (consumer loan).

2. Berdasarkan Jangka Waktu, antara lain: a. Kredit jangka pendek; b. Kredit jangka menengah; c. Kredit jangka panjang.

3. Berdasarkan jaminan, antara lain: a. Kredit dengan jaminan; b. Kredit tanpa jaminan.

4. Berdasarkan sektor ekonomi, antara lain: a. Kredit sektor pertanian pertanian; b. Kredit sektor pertambangan. d. Kredit sektor perdagangan,restoran,dan hotel; e.

Kredit Sektor lainnya.

Kualitas kredit disebut juga kualitas aktiva produktif. Aktiva Produktif adalah penanaman dana bank baik dalam rupiah maupun valuta asing dalam bentuk kredit, surat berharga, penempatan dana antar bank penyertaan, termasuk komitmen dan kontinjensi pada transaksi rekening administratif (SK Direksi BI :1998). Aktiva produktif dapat juga dikatakan semua aktiva yang di miliki bank dengan maksud untuk memperoleh penghasilan sesuai fungsinya, sehingga kredit merupakan salah satu bentuk dan aktiva produktif.

Berdasarkan Peraturan Bank Indonesia No. 8/19/PBI/2006 tentang kualitas aktiva produktif dan penyisihan penghapusan aktiva produktif Bank Perkreditan Rakyat dibagi atas 4 yaitu: lancar, kurang lancar, diragukan dan macet. Bank wajib membentuk penyisihan penghapusan aktiva produktif (PPAP) untuk menutup resiko kemungkinan kerugian dengan pedoman sebagai berikut:

p.ISSN: 2407-800X e.ISSN: 2541-4356 
a. Cadangan umum PPAP sekurangkurangnya $0,5 \%$ dari aktiva produktif yang digolongkan lancar, tidak termasuk Sertifikat Bank Indonesia.

b. Cadangan umum PPAP sekurangkurangnya $10 \%$ dari aktiva produktif yang digolongkan kurang lancar setelah dikurangi nilai agunan.

c. Cadangan umum PPAP sekurangkurangnya $50 \%$ dari aktiva produktif yang digolongkan diragukan setelah dikurangi agunan.

d. Cadangan umum PPAP sekurangkurangnya $100 \%$ dari aktiva produktif yang digolongkan macet setelah dikurangi nilai agunan.

Profitabilitas suatu perusahaan menunjukkan perbandingan antara laba dengan aktiva/modal yang menghasilkan laba tersebut. Dengan kata lain, profitabilitas merupakan kemampuan suatu perusahaan untuk menghasilkan laba selama periode tertentu (Riyanto, 2001).

Dalam dunia perbankan, tingkat profitabilitas adalah faktor yang mempengaruhi tingkat kesehatan bank selain faktor modal, kualitas, aktiva, manajemen dan likuiditas. Menurutt Abdullah (2003), profitabilitas adalah kemampuan bank dalam menghasilkan profit melalui operasi bank. Tingkat profitabilitas Bank Perkreditan Rakyat (BPR) mencerminkan keberhasilan atau kegagalan manajemen BPR dalam mengelola atau menanamkan dana yang tersedia pada aktiva produktif untuk memperoleh bunga atau penghasilan serta pengaturan pembiayaan yang harus dikeluarkan untuk menunjang operasional BPR yang bersangkutan

\section{METODE}

Penelitian ini menggunakan metode analisis jalur (Path Analisis). Populasi dalam penelitian ini adalah seluruh BPR Konvensional yang ada di Riau dengan menggunakan sampel jenuh berjumlah 33 (tiga puluh tiga). Sampel penelitian diperoleh dengan melakukan sensus data BPR Konvensional yang terdaftar di Perbarindo Riau periode 2009-2013 dan Otorisasi Jasa Keuangan 2014. Data yang digunakan dalam penelitian ini adalah data sekunder. Data penelitian diperoleh dengan melakukan sensus data BPR yang terdaftar di Perbarindo Riau periode 2009-2013. Data penelitian juga diperoleh dari Laporan Publikasi BPR yang terdapat di website

\section{HASIL}

Statistik deskriptif memberikan gambaran atau deskriptif suatu data yang dilihat dari nilai rata-rata (mean), standar deviasi, varian, nilai maksimal dan nilai minimum (Ghozali, 2015-19).

Data penelitian ini menyangkut lima variabel yaitu dua variabel terikat dan tiga variabel bebas. Variabel terikat (Y1) adalah Non Performing Loan (NPL) dan (Y2) adalah Return On Asset (ROA), sedangkan variabel bebas pertama (X1) adalah Kredit Modal Kerja, (X2) adalah Kredit Investasi dan variabel bebas ketiga (X3) adalah Kredit Konsumsi.

Berdasarkan hasil statistic dapat dilihat bahwa $\mathrm{N}$ atau jumlah data yang valid untuk NPL (Non Performing Loan), ROA (Return On Asset), KI (Kredit Investasi), KMK (Kredit Modal Kerja), KK (Kredit Konsumsi) adalah sebanyak 165 sampel. Untuk kredit modal kerja memiliki nilai maksimum (75.02), nilai minimum (42.03), rata-rata (54.42) dan standar deviasi (8.24). Kredit Investasi memiliki nilai maksimum (23.56), nilai minimum (0.08), rata-rata (6.96) dan standar deviasi (4.88). Kredit konsumsi memiliki nilai maksimum (61.25), nilai minimum (15.48), rata-rata (34.75) dan standar deviasi (8.44). NPL memiliki nilai maksimum (45.00), nilai minimum (0.02), rata-rata (6.26) dan standar deviasi (7.29). ROA memiliki nilai maksimum (41.00), nilai minimum ($19.00)$, rata-rata (4.67) dan standar deviasi (5.88).

Berdasarkan nilai KolmogrovSmirnov sebesar 0.632 lebih besar dari 0.05 artinya bahwa residual terdistribusi secara

p.ISSN: $2407-800 X \quad$ e.ISSN: 2541-4356 
normal.

Nilai koefisien determinasi portofolio kredit terhadap NPL dan ROA menghasilkan dua koefisien determinasi yaitu: $\mathrm{R}_{1}{ }^{2}=0.036$ dan nilai $\mathrm{R}_{2}^{2}=0.054$. Dengan demikian koefisien determinasi ini dapat di transformasikan ke dalam rumus: 1 - (1 $\left.\mathrm{R}_{1}{ }^{2}\right)\left(1-\mathrm{R}_{2}^{2}\right)=1-(0.964 \times 0.946)=1-$ $0.9119=0.0881$ yang berarti bahwa variabel bebas (kredit modal kerja, kredit investasi, kredit konsumsi) mempengaruhi variabel terikat (kualitas kredit dan profitabilitas) adalah sebesar $8.81 \%$. sedangkan sisanya $91.19 \%$ dipengaruhi oleh faktor-faktor lain yang tidak dijelaskan dalam penelitian ini.

Hasil Pengujian Jalur Tahap Pertama

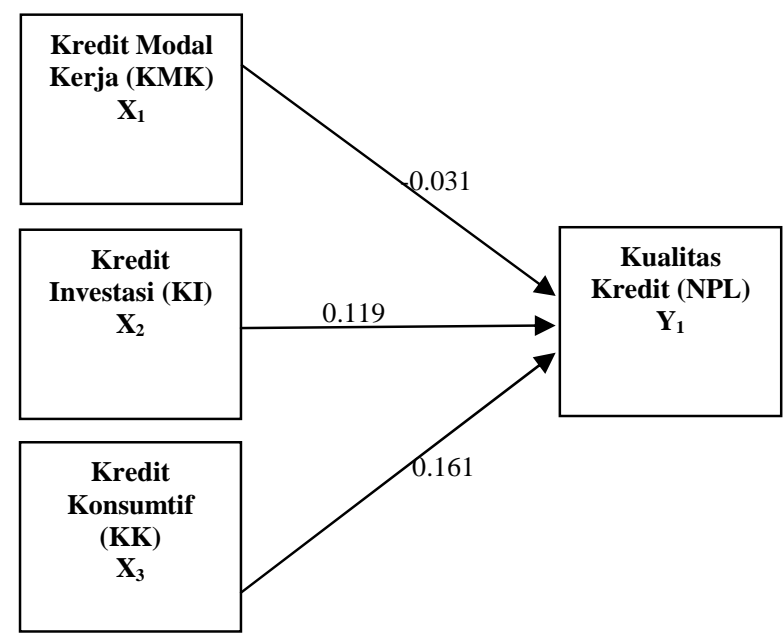

Gambar 1.: Hasil Pengujian

Konstrak Tahap Pertama

Berdasarkan Gambar 1. dapat dihasilkan sebuah persamaan berikut:

$\mathrm{Yi}=-0.031 \mathrm{X} 1+0.0119 \mathrm{X} 2+0.161 \mathrm{X} 3+\mathrm{e}_{1}$ dimana:

- Gambar 2 juga didapatkan persamaan: $X_{2}=0,030 X_{1}$ yang berarti bahwa setiap peningkatan sebesar 1 satuan pada variabel kredit modal kerja maka kredit investasi akan meningkat sebesar 0,030 .

- Gambar 2 juga didapatkan persamaan: $X_{3}=0,157 X_{2}$ yang berarti bahwa setiap peningkatan sebesar 1 satuan pada variabel kredit investasi maka kredit konsumsi akan meningkat sebesar 0,157 .

Berdasarkan hasil pengujian koefisien determinasi diperoleh informasi sebagaimana dilihat pada tabel berikut:

Tabel 1.: Hasil Pengujian Koefisien Determinasi $\quad\left(\mathrm{R}^{2}\right) \quad$ Tahap Pertama

\begin{tabular}{|l|c|l|l|l|}
\hline Model & $\mathrm{R}$ & $\begin{array}{c}\mathrm{R} \\
\text { Square }\end{array}$ & $\begin{array}{c}\text { Adjusted R } \\
\text { Square }\end{array}$ & $\begin{array}{c}\text { Std. Error of the } \\
\text { Estimate }\end{array}$ \\
\hline 1 & $.191^{\mathrm{a}}$ & .036 & .018 & 7.23059 \\
\hline
\end{tabular}

a. Predictors: (Constant), Modal Kerja, Investasi, Konsumsi

Sumber: Data Olahan Tahun 2014

Dari Tabel 1. dapat dihitung nilai error pada pengujian konstrak pertama yaitu: nilai $\mathrm{e}_{1} \quad\left(1-\mathrm{R}^{2}\right) \rightarrow(1-0,036)=$ $0,964 \times 100 \%=96.4 \%$ yang berarti bahwa kemampuan variabel kredit modal kerja, kredit investasi dan kredit konsumsi dalam menjelaskan variasi yang terjadi pada variabel NPL hanya sebesar $3.6 \%$ sedangkan $96.4 \%$ sisanya dipengaruhi oleh faktor-faktor lain yang tidak dibahas dalam penelitian ini.

Sementara itu hasil pengujian parsial menunjukkan informasi sebagaimana tabel berikut ini:

Tabel 2: Hasil Pengujian Parsial Tahap Pertama

\begin{tabular}{|l|l|l|c|c|}
\hline Variabel & $\mathbf{t}_{\text {hitung }}$ & $\mathbf{T}_{\text {tabel }}$ & Sig. & $\boldsymbol{\alpha}$ \\
\hline KMK & 3.396 & 1.960 & 0.032 & 0.05 \\
KI & 2.023 & 1.960 & 0.000 & 0.05 \\
KK & 2.032 & 1.960 & 0.044 & 0.05 \\
\hline
\end{tabular}

Dari hasil pengujian parsial, nilai thitung kredit modal kerja $3.396>$ ttabel 1.960 dengan nilai sig. $0.032<0.05$ Hasil ini menunjukkan bahwa kredit modal kerja berpengaruh signifikan terhadap kualitas kredit (NPL). Implementasinya adalah, semakin tinggi kredit modal kerja maka kualitas kredit (NPL) semakin tinggi. Sebaliknya, jika kredit modal kerja semakin rendah maka kualitas kredit (NPL) semakin rendah.

Dari hasil pengujian parsial, nilai thitung kredit investasi $2.023>$ ttabel 1.960 dengan nilai sig. $0.000<0.05$ Hasil ini menunjukkan bahwa kredit investasi berpengaruh signifikan terhadap kualitas kredit (NPL). Implementasinya adalah, semakin tinggi kredit investasi maka

p.ISSN: 2407-800X e.ISSN: 2541-4356 
kualitas kredit (NPL) semakin tinggi. Sebaliknya, jika kredit investasi semakin rendah maka kualitas kredit (NPL) semakin rendah.

Dari hasil pengujian parsial, nilai thitung kredit konsumsi $2.032>$ ttabel 1.960 dengan nilai sig. $0.044<0.05$ Hasil ini menunjukkan bahwa kredit konsumsi berpengaruh signifikan terhadap kualitas kredit (NPL). Implementasinya adalah, semakin tinggi kredit konsumsi maka kualitas kredit (NPL) semakin tinggi. Sebaliknya, jika kredit investasi semakin rendah maka kualitas kredit (NPL) semakin rendah. Bahkan hasil pengujian menunjukkan bahwa nilai koefisien regresi dan nilai thitung variable kredit konsumsi lebih tinggi dibandingkan dengan variable kredit modal kerja maupun kredit investasi. Dengan hasil ini maka kredit konsumsi menjadi factor dominan yang mempengaruhi kualitas kredit (NPL).

\section{Hasil Pengujian Jalur Tahap Kedua}

Pengujian jalur tahap kedua dilakukan pada variabel kredit modal kerja, kredit investasi, kredit konsumsi dan kualitas kredit (NPL) sebagai variabel independen terhadap kualitas kredit sebagai variabel dependen. Hasil pengujian menghasilkan sebuah persamaan regresi, nilai koefisien determinasi, pengujian simultan dan parsial yang rasing-musing akan dijelaskan selanjutnya.

Nilai koefisien determinasi variabel kredit modal kerja, kredit investasi, kredit konsumsi dan kualitas kredit (NPL) digambarkan dalam konstrak berikut ini:

\section{Hasil Pengujian Jalur Tahap Kedua}

Berdasarkan Gambar 3. dapat dihasilkan sebuah persamaan regresi berikut: $\mathrm{Yi}=0,040 \mathrm{X}_{1}+0.005 \mathrm{X}_{2}+-0.078 \mathrm{X}_{3}$ $+-0.0201 \mathrm{Y}_{1}+\mathrm{e}_{2}$ dimana :

- Nilai koefisien sebesar $0.040 \mathrm{X}_{1}$ artinya adalah untuk setiap peningkatan sebesar 1 satuan pada variabel kredit modal kerja dimana variable lainnya diasumsikan konstan, maka profitabilitas akan meningkat sebesar 0.040 .

- Nilai koefisien sebesar $0.005 \mathrm{X}_{2}$ artinya adalah untuk setiap peningkatan sebesar 1 satuan pada variabel kredit investasi dimana variable lainnya diasumsikan konstan, maka profitabilitas akan meningkat sebesar 0.005 .

- Nilai koefisien sebesar $-0.078 \mathrm{X}_{3}$ artinya adalah untuk setiap penurunan sebesar 1 satuan pada variabel kredit investasi dimana variable lainnya diasumsikan konstan, maka profitabilitas akan menurun sebesar -0.078 .

- Nilai koefisien sebesar $-0.020 Y_{1}$ artinya adalah untuk setiap penurunan sebesar 1 satuan pada variable kualitas kredit (NPL) dimana variable lainnya diasumsikan konstan, maka profitabilitas akan menurun sebesar -0.020 .

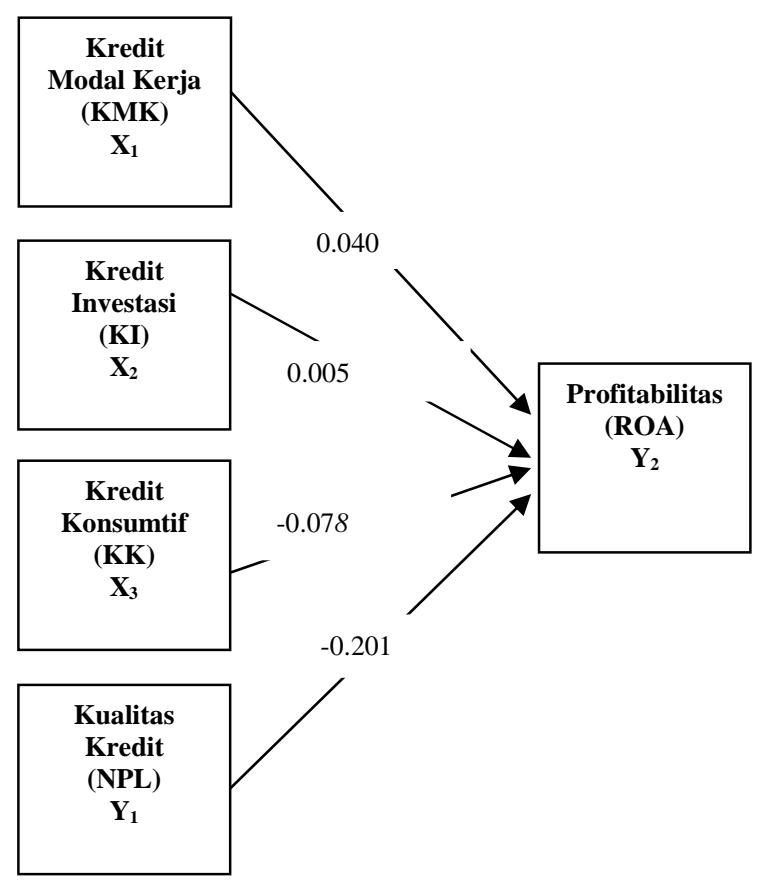

Gambar 2.: Hasil Pengujian Konstrak Tahap Kedua

Berdasarkan hasil pengujian koefisien determinasi diperoleh informasi sebagaimana tabel berikut ini: 
Tabel 3.: Hasil Pengujian Koefisien Determinasi $\left(\mathrm{R}^{2}\right)$ Tahap Kedua

\begin{tabular}{|l|c|c|l|l|}
\hline Model & $\mathrm{R}$ & $\begin{array}{c}\mathrm{R} \\
\text { Square }\end{array}$ & $\begin{array}{c}\text { Adjusted R } \\
\text { Square }\end{array}$ & $\begin{array}{c}\text { Std. Error of the } \\
\text { Estimate }\end{array}$ \\
\hline 1 & $.233^{\mathrm{a}}$ & .054 & .031 & 5.79069 \\
\hline $\begin{array}{l}\text { a. Predictors: (Constant), NPL, } \\
\text { KMK, KI, KK }\end{array}$ & \\
\hline
\end{tabular}

Sumber: Data Olahan Tahun 2014

Dari Tabel 3. dapat dihitung nilai error pada pengujian konstrak kedua yaitu: nilai $\mathrm{e}_{2}$ $\left(1-\mathrm{R}^{2}\right) \quad(1-0,054)=0,946 \times 100 \%=$ $94.6 \%$ yang berarti bahwa kemampuan variabel kredit modal kerja, kredit investasi, kredit konsumsi dan kualitas kredit dalam menjelaskan variasi yang terjadi pada variabel profitabilitas (ROA) hanya sebesar $5.4 \%$ sedangkan $94.6 \%$ sisanya dipengaruhi oleh faktor-faktor lain yang tidak dibahas dalarn penelitian ini.

Sementara itu hasil pengujian parsial menunjukkan informasi sebagaimana tabel berikut ini:

Tabel 4.: Hasil Pengujian Parsial Tahap Kedua

\begin{tabular}{|l|c|c|c|c|}
\hline \multicolumn{1}{|c|}{ Variabel } & $\mathbf{t}_{\text {hitung }}$ & $\mathbf{t}_{\text {tabel }}$ & Sig. & $\boldsymbol{\alpha}$ \\
\hline KMK & 2.512 & 1.960 & 0.012 & 0.05 \\
KI & 3.263 & 1.960 & 0.033 & 0.05 \\
KK & 4.078 & 1.960 & 0.032 & 0.05 \\
NPL & 3.201 & 1.960 & 0.000 & 0.05 \\
\hline
\end{tabular}

Sumber: Data Olahan Tahun 2014

Dari hasil pengujian parsial, nilai $\mathrm{t}_{\text {hitung }}$ kredit modal kerja $2.512>\mathrm{t}_{\text {tabel }} 1.960$ dengan nilai sig. $0.012<0.05$ Hasil ini menunjukkan bahwa kredit modal kerja berpengaruh signifikan terhadap profitabilitas (ROA). Implementasinya adalah, semakin tinggi kredit modal kerja maka profitabilitas (ROA) semakin tinggi. Sebaliknya, jika kredit modal kerja semakin rendah maka profitabilitas (ROA) semakin rendah.

Dari hasil pengujian parsial, nilai $\mathrm{t}_{\text {hitung }}$ kredit investasi $3.263>\mathrm{t}_{\text {tabel }} 1.960$ dengan nilai sig. $0.033<0.05$ Hasil ini menunjukkan bahwa kredit investasi berpengaruh signifikan terhadap profitabilitas
(ROA). Implementasinya adalah, semakin tinggi kredit investasi maka profitabilitas (ROA) semakin tinggi. Sebaliknya, jika kredit investasi semakin rendah maka profitabilitas (ROA) semakin rendah.

Dari hasil pengujian parsial, nilai $\mathrm{t}_{\text {hitung }}$ kredit konsumsi $4.078>\mathrm{t}_{\text {tabel }} 1.960$ dengan nilai sig. $0.032<0.05$ Hasil ini menunjukkan bahwa kredit konsumsi berpengaruh signifikan terhadap profitabilitas (ROA). Implementasinya adalah, semakin tinggi kredit konsumsi maka profitabilitas (ROA) semakin tinggi. Sebaliknya, jika kredit konsumsi semakin rendah maka profitabilitas (ROA) semakin rendah.

Dari hasil pengujian parsial, nilai $\mathrm{t}_{\text {hitung }}$ kualitas kredit (NPL) $3.201>\mathrm{t}_{\text {tabel }}$ 1.960 dengan nilai sig. $0.000<0.05$ Hasil ini menunjukkan bahwa kualitas kredit (NPL) berpengaruh signifikan terhadap profitabilitas (ROA). Implementasinya adalah, semakin tinggi kualitas kredit (NPL) maka profitabilitas (ROA) semakin tinggi. Sebaliknya, jika kualitas kredit (NPL) semakin rendah maka profitabilitas (ROA) semakin rendah.

\section{Hasil Pengujian Analisis Jalur}

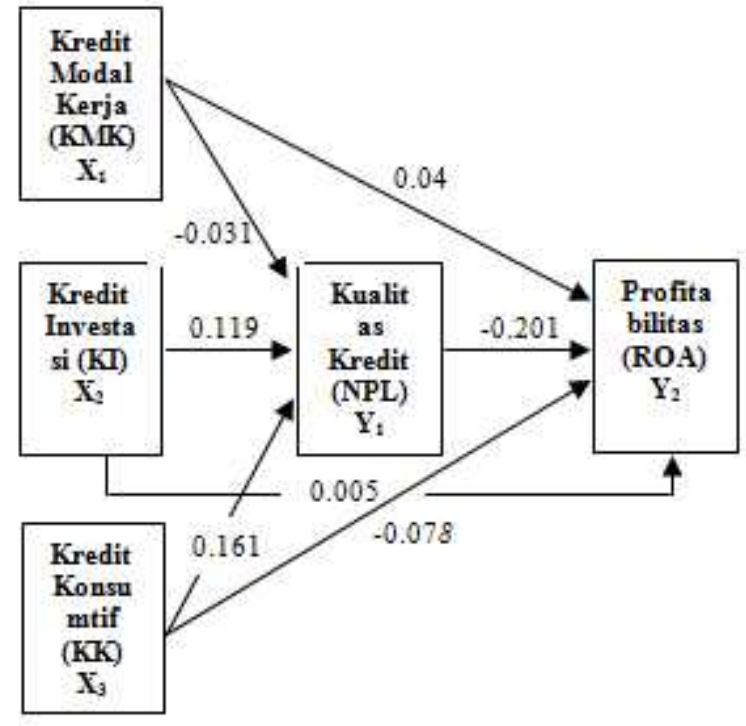

Gambar 3.: Analisis Jalur

Penjelasan diagaram pada Gambar 3 dapat diuraikan sebagai berikut : 
1. Kontribusi langsung dan tidak langsung variable kredit modal kerja terhadap profitabilitas (ROA)

a. Besar kontribusi langsung variabel kredit modal kerja terhadap profitabilitas (ROA) adalah $0.040^{2}$ $\mathrm{x} 100 \%=0.16 \%$

b. Besar kontribusi tidak langsung kredit modal kerja terhadap profitabilitas (ROA) melalui kualitas kredit adalah: $-0.031 \mathrm{x}$ $0.201=0.0062$

c. Total kontribusi kredit modal kerja terhadap profitabilitas (ROA) adalah $=0.040+0,0062=0,0462$

2. Kontribusi langsung dan tidak langsung variable kredit investasi terhadap profitabilitas (ROA)

a. Besar kontribusi langsung variabel kredit investasi terhadap profitabilitas (ROA) adalah $0.005^{2} \mathrm{x}$ $100 \%=0.0025 \%$

b. Besar kontribusi tidak langsung kredit investasi terhadap profitabilitas (ROA) melalui kualitas kredit adalah: $0.119 \times-0.201=$ 0.0239

c. Total kontribusi kredit investasi terhadap profitabilitas (ROA) adalah $=0.0025+0,0239=0,0214$

3. Kontribusi langsung dan tidak langsung variable kredit konsumsi terhadap profitabilitas (ROA)

a. Besar kontribusi langsung variabel kredit konsumsi terhadap profitabilitas (ROA) adalah $-0.078^{2}$ $\mathrm{x} 100 \%=0.00608 \%$

b. Besar kontribusi tidak langsung kredit konsumsi terhadap profitabilitas (ROA) melalui kualitas kredit adalah: $\mathrm{x}-0.201=-0.0323$

c. Total kontribusi kredit konsumsi terhadap profitabilitas (ROA) adalah $=-0.078+-0.033=-0.111$

4. Kontribusi langsung variable kualitas kredit (NPL) terhadap variable profitabilitas adalah sebesar $-0.201^{2} \mathrm{x}$ $100 \%=4.0401 \%$

\section{PEMBAHASAN}

Pembahasan hasil penelitian untuk menjawab hipotesis penelitian yang telah dirumuskan sebelumnya.

\section{Pengaruh Kredit Modal Kerja Secara Langsung Terhadap Profitabilitas}

Dari hasil penelitian diatas, dapat dilihat bahwa kredit modal kerja berpengaruh signifikan terhadap profitabilitas (ROA). Hal ini mengindikasikan bahwa semakin tinggi kredit modal kerja pada bank maka akan semakin tinggi profitabilitas (ROA) bank tersebut. Sebaliknya, jika kredit modal kerja mengalami penurunan, maka profitabilitas bank tersebut juga menurun.

Penilitian ini secara teoritis menguatkan landasan teori yang dikemukakan oleh Abdullah dan Tantri (2012:172) bahwa dalam pemberian kredit modal kerja harus diperhatikan tingkat pengembalian kredit tersebut, karena kredit modal kerja mempengaruhi kegagalan ataupun keberhasilan bank yang dapat di ukur melalui profitabilitas (ROA) bank tersebut. Penilitia ini juga menyimpulkan bahwa semakin tinggi pemberian kredit modal kerja, maka performa bank tersebut juga semakin baik, karena kemampuan bank untuk memperoleh keuntungan semakin besar. Sebaliknya, jika kredit modal kerja mengalami penurunan, maka kemampuan bank dalam memperoleh laba juga menurun. Hasil penelitian ini senada dengan penelitian yang dilakukan oleh Meydianawathi (2007) menyatakan bahwa kredit modal kerja berpengaruh terhadap profitabilitas (ROA).

Juga memperkuat konsep bahwa informasi dari suatu perusahaan lazimnnya didasarkan pada kinerja perusahaan yang tercermin dari laporan keuangannya, dari laporan keuangan tersebut investor dapat mengetahui kenerja dari perusahaan tersebut.(Murnawati, 2016) 
Pengaruh Kredit Modal Kerja Melalui Kualitas Kredit Secara Tidak Langsung Terhadap Profitabilitas

Dari hasil penelitian diatas, diketahui bahwa kredit modal kerja melalui kualitas kredit berpengaruh signifikan terhadap profitabilitas (ROA). Implimentasinya adalah semakin besar kredit modal kerja melalui kualitas kredit maka profitabilitas juga semakin meningkat. Sebaliknya, jika kredit modal kerja melalui kualitas kredit semakin kecil, maka profitabilitass juga semakin menurun.

Hasil penelitian ini menguatkan landasan teori yang dikemukakan oleh Hasibuan (2011:100) yaitu kredit modal kerja berpengaruh terhadap NPL dan profitabilitas bank, semakin tinggi kredit modal kerja, maka NPL semakin menurun dan profitabilitas (ROA) bank semakin meningkat. Penilitian ini juga menyimpulkan bahwa peranan kualitas kredit (NPL) sangat mempengaruhi kemampuan bank dalam menghasilkan laba. Jika NPL bank tersebut meningkat, maka bank akan mengalami kegagalan karena tingkat pengembalian kredit mengalami kemacetan atau terjadi kesalahan dalam pemberian kredit yang tidak tepat sasaraan.

Sehingga peranan NPL sebagai intervening dalam kredit investasi sangat mempengaruhi profitabilitas bank tersebut. Hasil penelitian ini senada dengan penelitian yang dilakukan oleh Ira (2005) tentang pengaruh modal kerja terhadap profitabilitas yang menyimpulkan bahwa modal kerja yaitu perputaran kas mempunyai pengaruh yang signifikan terhadap perusahaan. Berbeda dengan penelitian yang dilakukan oleh Febriansyah (2007) yang menyatakan bahwa NPL tidak berpengaruh terhadap kredit modal kerja.

Pengaruh Kredit Investasi Secara Langsung Terhadap Profitabilitas

Dari hasil penelitian diatas, dapat dilihat bahwa kredit investasi berpengaruh signifikan terhadap profitabilitas (ROA).
Implimentasinya adalah semakin besar kredit investasi maka profitabilitas juga semakin meningkat. Hal ini mengindikasikan bahwa semakin tinggi kredit investasi pada bank maka akan semakin tinggi profitabilitas (ROA). Hal ini mungkin disebabkan dengan adanya kredit investasi menjadikan bank mendapatkan profitabilitas (ROA) yang tinggi.

Secara teoritis, kesimpulan penelitian ini menguatkan landasan teori yang dikemukanan oleh Kasmir (2014:127) bahwa jika kredit investasi meningkat akan mempengaruhi profitabilitas bank tersebut juga mengalami peningkatan. Hasil penelitian ini juga senada dengan penelitian yang dilakukan oleh Mahrianasari (2003) menyatakan bahwa portofolio kredit BPR yang diukur secara total di Bandar Lampung berpengaruh terhadap profitabilitas.

Pengaruh Kredit Investasi Melalui Kualitas Kredit Secara Tidak Langsung Terhadap Profitabilitas

Dari hasil penelitian diatas, dapat dilihat bahwa kredit investasi melalui kualitas kredit berpengaruh signifikan terhadap profitabilitas (ROA). Implimentasinya adalah semakin tinggi kredit investasi melalui kualitas kredit, maka profitabilitas (ROA) juga semakin tinggi. Sebaliknya, jika kredit investasi melalui kualitas kredit semakin kecil, maka profitabilitas (ROA) juga semakin menurun.

Hasil penelitian ini secara teoritis mendukung landasan teori yang dikemukanan oleh Kasmir (2014:127) bahwa kredit investasi melalui kualitas kredit sangat berpengaruh terhadap profitabilitas, semakin tinggi kredit macet maka kemampuan bank dalam menghasilkan laba semakin menurun.

Hasil penelitian ini juga menyimpulkan bahwa kualitas kredit dalam hal ini adalah NPL mempunyai pengaruh yang sangat besar terhadap ROA bank, sehingga dalam pemberian kredit investasi

p.ISSN: $2407-800 X \quad$ e.ISSN: $2541-4356$ 
harus diperhatikan resiko keungan yang akan muncul nantinya, jika kredit investasi meningkat dan NPL menurun, maka ROA bank juga meningkat. Sebaliknya, jika kredit investasi menurun dan NPL meningkat, maka bank mengalami kegagalan atau profitabilitas bank menurun.

Hasil penelitian ini senada dengan penelitian yang dilakukan oleh Edrian (2008) menyatakan bahwa secara individu kredit investasi berpengaruh terhadap Non Performing Loan.

Pengaruh Kredit Konsumsi Secara Langsung Terhadap Profitabilitas

Dari hasil penelitian diatas, dapat dilihat bahwa kredit konsumsi mempunyai hubungan tidak searah (negatif) terhadap profitabilitas (ROA). Implimentasinya adalah semakin tinggi kredit konsumsi maka profitabilitas juga semakin menurun. Sebaliknya, jika kredit kosumsi semakin kecil, maka profitabilitass semakin meningkat. Hal ini disebabkan karena kredit konsumsi dipergunakan untuk kebutuhan pribadi debitur tanpa adanya perputaran modal kerja yang signifikan terhadap pendapatan debitur.

Hasil penelitian ini menguatkan landasan teori yang dikemukakan oleh Supriyono (2011:80) bahwa kredit konsumsi mempunyai hubungan yang tidak searah dengan profitabilitas bank. Semakin tinggi kredit konsumsi, maka kemampuan bank dalam memperoleh keuntungan semakin menurun, karena dalam pemberian kredit konsumsi tidak ada pertambahan barang atau jasa yang dihasilkan karena digunakan atau dipakai oleh seseorang atau badan usaha. Hasil penelitian ini menguatkan penelitian yang dilakukan oleh Febriansyah (2007) yang menyatakan bahwa secara individu kredit konsumsi mempunyai hubungan yang tidak searah dengan profitabilitas.

Pengaruh Kredit Konsumsi Melalui Kualitas Kredit Terhadap Profitabilitas

Dari hasil penelitian diatas, dapat dilihat bahwa kredit konsumsi melalui kualitas kredit berpengaruh signifikan terhadap profitabilitas (ROA). Implimentasinya adalah semakin tinggi kredit konsumsi melalui kualitas kredit, maka profitabilitas (ROA) bank semakin menurun. Hal ini mengindikasikan bahwa semakin tinggi kredit konsumsi pada bank maka kualitas kredit (NPL) juga semakin meningkat, sehingga profitabilitas bank (ROA) semakin menurun.

Secara teoritis, penilitian ini mendukung landasan teori yang dikemukanan oleh Supriyono (2011:124) yaitu kredit konsumsi berpengaruh terhadap NPL tetapi mempunyai hubungan yang tidak searah dengan ROA. Hal ini mungkin disebabkan kredit konsumsi digunakan untuk keperluan pribadi, semakin besar kredit konsumsi masyarakat maka kualitas kredit (NPL) atau kegagalan tingkat pengembalian juga semakin meningkat, sehingga ROA bank semakin menurun. Hasil penelitian ini senada dengan penelitian yang dilakukan oleh Mahrinasari (2003) menyatakan bahwa portofolio kredit BPR yang diukur secara total di Bandar Lampung berpengaruh terhadap profitabilitas dan pengelolaan kredit. Pengaruh Kualitas Kredit Terhadap
Profitabilitas

Dari hasil penelitian diatas juga dapat dilihat bahwa kualitas kredit (NPL) berpengaruh signifikan terhadap profitabilitas (ROA). Maknanya adalah semakin rendah kredit bermasalah (NPL) maka semakin tinggi kemampuan perusahaan untuk menghasilkan laba (ROA). Sebaliknya, jika kualitas kredit (NPL) mengalami peningkatan, artinya terjadi kemacetan dalam pelunasan kredit oleh debitur. Hal ini berdampak sangat tidak baik bagi perusahaan, karena meningkatnya kredit bermasalah berpengaruh terhadap kinerja keuangan perusahaan. Semakin rendah NPL maka kemampuan perusahaan secara keseluruhan untuk menghasilkan keuntungan atau dalam

p.ISSN: $2407-800 X \quad$ e.ISSN: 2541-4356 
kata lain untuk menggambarkan produktivitas bank semakin baik.

Hasil penelitian ini secara teoritis menguatkan landasan teori yang dikemukakan oleh Siamat (2005:358) bahwa kredit bermasalah (NPL) dapat diartikan sebagai pinjaman yang mengalami kesulitan pelunasan akibat adanya faktor kesengajaaan dan atau karena faktor eksternal diluar kendali debitur yang dapat mempengaruhi profitabilitas perusahaan. Artinya semakin tinggi kredit bermasalah (NPL) maka akan semakin buruk kualitas kredit bank yang menyebabkan jumlah kredit bermasalah semakin besar yaitu kerugian yang diakibatkan tingkat pengembalian kredit macet.

Secara teoritis, kesimpulan penelitian ini mendukung kesimpulan penelitian Wulandari, et,al (2013:99.116) kenaikan kredit bermasalah akan mempengaruhi penurunan terhadap laba perusahaan, sehingga NPL mempunyai hubungan tidak searah (negatif) terhadap profitabilitas. Artinya profitabilitas akan tergantung pada besar kecilnya kredit bermasalah yang dihadapi oleh perusahan. Hal ini juga sejalan dengan yang dikemukakan oleh Sutoyo (2008:25) sebuah bank yang dirongrong kredit bermasalah dalam jumlah besar cenderung menurun profitabilitasnya, akibatnya nilai kesehaatan operasi di masyarakan dan di dunia perbankan khususnya akan ikut menurun.

Hasil penelitian ini senada dengan penelitian yang dilakukan oleh Budiman (2012) yang menyatakam bahwa hasil perhitungan kualitas kredit dengan menggunakan perhitungan NPL memiliki pengaruh signifikan terhadap profitabilitas bank baik pada ROE maupun ROA. Selanjutnya penelitian yang sama yaitu Siagian (2009) menyatakan bahwa variabel NPL, CAR, LDR, dan KAP berpengaruh terhadap ROA. Berbeda dengan penelitian yang dilakukan oleh Zainah (2005) menyatakan bahwa NPL tidak berpengaruh terhadap ROA.

Penelitian ini juga menyimpulkan bahwa kualitas kredit merupakan faktor utama yang menjadi salah satu tolak ukur keberhasilan bank. Tingginya NPL akan mengakibatkan bank mengalami kerugian yang bisa dilihat dari berbagai faktor, baik faktor internal maupun eksternal bank. Sementara itu, tingginya NPL juga berdampak terhadap dunia perbankan karena bisa menyebabkan menurunnya tingkat kepercayaan masyarakat terhadap dunia perbankan.

Bagi perbankan hasil akhir penilaian kondisi bank dapat digunakan sebagai salah satu kemampuan bank untuk mengetahui apakah bank tersebut sehat atau tidak sehat, yang mengakibatkan turunnya profitabilitas perbankan tersebut. Dengan demikian dapat disimpulkan apabila pengaruh kredit bermasalah meningkat akan mengakibatkan hilangnya kesempatan memperoleh laba atau profitabilitas bagi bank. Maka secara tidak langsung kegiatan operasional bank akan terganggu.

\section{SIMPULAN}

Hasil pengujian normalitas data menunjukkan bahwa selama tahun 20092013 variabel kualitas kredit dan profitabilitas berdistribusi normal. Hasil poengujian asumsi klasik terhadap data penelitian menunjukkan bahwa model regresi yang digunakan terbebas dari gangguan multikolienaritas, autokorelasi dan heterokedastisitas.

Hasil penujian analisis jalur menunjukkan bahwa jalur 1, 2 dan 3 terdapat pengaruh yang signifikan terhadap profitabilitas, kredit investasi, kredit modal kerja dan kredit konsumtif berpengaruh terhadap kualitas kredit. Kualitas kredit berpengaruh signifikan profitabilitas. Secara simultan portofoio kredit berpengaruh terhadap kualitas kredit dan profitabilitas.

Factor-faktor yang mempengaruhi kebijakan portofolio kredit bank dibagi menjadi dua factor yaitu:

a. Factor internal yang meliputi: misi dan visi bank, pendanaan, modal bank, besaran asset yang di inginkan, kesediaan manajemen

p.ISSN: 2407-800X e.ISSN: 2541-4356 
dalam menanggung resiko dan factor sumber daya manusia.

b. Factor eksternal meliputi: kebijakan pemerintah, kondisi makro ekonomi dan lingkungan usaha lainnya.

\section{DAFTAR RUJUKAN}

Adam, Latil; 2009. Kredit Bermasalah, Penyebab dan Dampaknya. Harian Seputar Indonesia. P2E Lipi.

H. M, Jugiyanto. Teori Portofolio Dan Analisis Investasi. Edisi 2 BPFE. Yogyakarta.

Husnan, Suad., 2005. Dasar-Dasar Teori Portofolio dan Analisis Sekuritas. Edisi 4,UPP AMP YKPN,Yogyakarta.

Kasmir., 2014. Dasar-Dasar Perbankan, Edisi Revisi. PT. Raja Grafindo Persada, Jakarta.

Kuncoro, Mudjarat., dan Sukardjono., 2002. Manejemen Perbankan Teori dan Alplikasi. Yogyakarta.

Murnawati (2016) 'Analisis Payback Period Sebagai Dasar Kelayakan Investasi Murnawati'. pekanbaru: jurnal daya saing Vol 2 No 2 Jun 2016, pp. 117124.

Siamat, Dahlan., 2005. Manajemen Lembaga Keuangan: Kebijakan Moneter Dan Perbankan. Edisi Kelima, Fakultas Ekonomi Universitas Indonesia. Jakarta.
S.P. Hasibuan, Malayu., 2011. DasarDasar Perbankan. Cetakan ke-9, Bumi Aksara. Juli, 2011.

Sumanto., 2014. Statistik Terapan. Center for Academic Publishing Service, Yogyakarta.

Supriyono, Maryanto., 2010. Buku Pintar Perbankan. Penerbit ANDI, Yogyakarta.

Suhardjono., 2003. Manajemen Perkreditan. UPP-AMP YKPN, Yogyakarta.

---------, Otoritas Jasa Keuangan, 2014. ,Perbarindo Riau, 2014.

,Statistik Perbankan Indonesia, 2014. 